\title{
円環・液体系による角運動センサ*
}

\section{——解 析-}

\author{
西原主 計** \\ Angular Motion Sensor by a Torus Tube-Liquid System \\ - Analysis-
}

Kazue Nishinara

In order to understand the engineering mechanism of a semicircular canal of the living organisms and to set up the similar angular motion sensor, this paper deals with the dynamical analysis concerning a torus tube-liquid model which has a valve in the flow line, combining the theories of momentum of fluid flow, distortion or dislocation of the value, and spatial link motion of a dynamic sensing system. The sensing mechanism of the system is possible to express as a differential equation of the linear vibration type which senses angular acceleration under a large radius of the tube and a large spring coefficient of the valve. The leakage of fluid around the valve increases apparently both the spring coefficient of the valve and fluid friction.

Key words : angular motion sensor, angular acceleration, torus tube, flow in a torus tube, momentum of relative flow

\section{1. ま え がき}

脊椎動物に見られる半規管は, 円環状の細管の内部 にリンパ液が充満し，管路の一部の膨大した稜にゼラ チンに包まれた感覚毛群が突出し，それが弁とセンサ の役割をしている. 半規管の回転に応じてリンパ液が 流動するとき, 弁が変位し感覚有毛細胞が角運動を感 知する1).ここでは角速度, 角加速度運動を合わせて 角運動と呼ぶ2). 半規管は, ヒトのもので管半径が約 $0.3 \mathrm{~mm}$ と小さいため管摩摖が大きいので, 角速度検 出型となっている3.

本報告では, 半規管の働さを工学的に理解すること と, 角運動センサを構成することを目的として, 円環 容器・液体流動系のモデルを用い，その空間運動に招 ける大まかな動作メカニズムを解析した．空間りンク 系の運動, 円環内の液体流動, 弁の变形等の方程式を 結合して振動型の方程式を導き, 角加速度又は角速度 検出のための円環管径と弁のばね力の関係, 弁の構 造, 弁回りのもれの影響等を調べた.

* 原稿受付 平成 2 年 6 月 26 日. 1990 年度精密工学会春季 大会学術講演会 (平成 2 年 3 月 30 日) にて発表

** 正会員製品科学研究所 (つくば市東 1-1-4)

\section{2. 空間リンク系の運動}

ニュートン・オイラー法 ${ }^{2) 4}$ を用いて流体粒子の運動 を記述する。計測部・诗環系の坐標系は図 1 に示すよ らに, 静忆系を $\mathrm{K}_{0}$ 系, 原点 $\mathrm{O}_{i}$ をるつ動座標系を $\mathrm{K}_{i}$ 系とする. センサ部の座標系は, 便宜上計測点の座標 $\mathrm{K}_{n}$ 系から数光て $1,2, \cdots$ と取る. ベクトルの相対関係 として， $\mathrm{K}_{j}$ 系から見た $\mathrm{K}_{i}$ 系のベクトルは左肩にjを 付け，特に，一つの基準動座標 $\mathrm{K}_{m}$ 系から見るとき

unit vector at $\mathrm{K}_{3}$

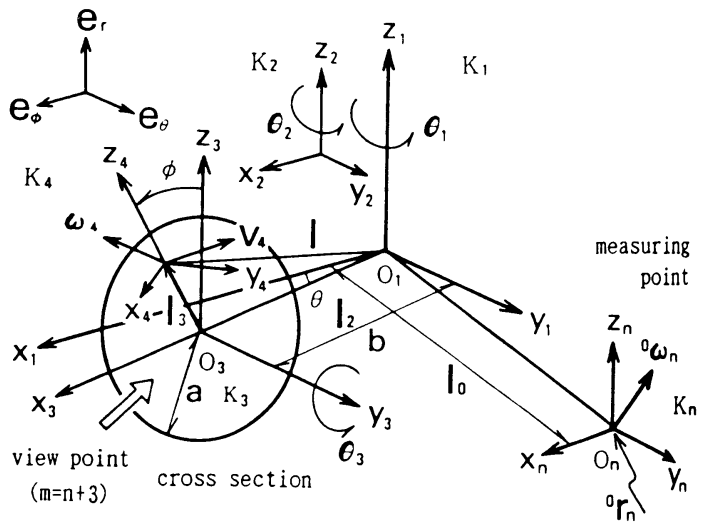

Fig. 1 Coordinate systems of spatial links and a torus tube 
Table 1 Components of relative vectors

\begin{tabular}{c|cccc}
\hline${ }^{i} \boldsymbol{l}_{i}$ & 0 & 1 & 2 & 3 \\
\hline \multirow{4}{*}{ Components } & $l_{01}$ & 0 & $b$ & 0 \\
& $l_{02}$ & 0 & 0 & 0 \\
& $l_{03}$ & 0 & 0 & $r$ \\
\hline${ }^{i} \boldsymbol{\theta}_{i}$ & 0 & 1 & 2 & 3 \\
\hline \multirow{3}{*}{ Components } & $\theta_{01}$ & $\theta_{11}$ & 0 & 0 \\
& $\theta_{02}$ & $\theta_{12}$ & 0 & $\phi$ \\
& $\theta_{03}$ & $\theta_{13}$ & $\theta$ & 0 \\
\hline
\end{tabular}

は，その添字を省略するものとする，運動体 $\mathrm{K}_{n}$ 系上 の計測部位を原点 $\mathrm{O}_{n}$ とし，それは ${ }^{0} \boldsymbol{r}_{n}$ の位置で角速 度 ${ }^{0} \omega_{n}$ で回転しているものとする. その先, 円環座 飘まで $\mathrm{O}_{i-1} \sim \mathrm{O}_{i}$ 間の相対距離を ${ }^{i-1} \boldsymbol{l}_{i-1}, \mathrm{~K}_{i}$ 系の姿 勢変化量を ${ }^{i-1} \boldsymbol{\theta}_{i}$ とする.

$\mathrm{K}_{i-1}$ 系から $\mathrm{K}_{i}$ 系への変換行列 ${ }^{i-1} \mathrm{~A}_{i}$ は

${ }^{i-1} A_{i}=\left(\begin{array}{ccc}\mathrm{C}_{2} \mathrm{C}_{3} & -\mathrm{C}_{2} \mathrm{C}_{3} & \mathrm{~S}_{2} \\ \mathrm{C}_{1} \mathrm{~S}_{3}+\mathrm{S}_{1} \mathrm{~S}_{2} \mathrm{C}_{3} & \mathrm{C}_{1} \mathrm{C}_{3}-\mathrm{S}_{1} \mathrm{~S}_{2} \mathrm{~S}_{3} & -\mathrm{S}_{1} \mathrm{C}_{2} \\ \mathrm{~S}_{1} \mathrm{~S}_{3}-\mathrm{C}_{1} \mathrm{~S}_{2} \mathrm{C}_{3} & \mathrm{~S}_{1} \mathrm{C}_{3}+\mathrm{C}_{1} \mathrm{~S}_{2} \mathrm{~S}_{3} & \mathrm{C}_{1} \mathrm{C}_{2}\end{array}\right)$

である.ここに, $\mathrm{S}_{j}, \mathrm{C}_{j}$ は表 1 の成分 $\theta_{i j}$ の正弦, 余 弦関数である. 一般べクトル ${ }^{i} \boldsymbol{q}_{i}$ に関し変換則は

$$
{ }^{k} \boldsymbol{q}_{i}={ }^{k} \mathrm{~A}_{i}{ }^{i} \boldsymbol{q}_{i}
$$

である*.

図 1 において，基準動坐標を $\mathrm{K}_{3}$ 系とし，川環内の |注目する流体粒子の夾標を $\mathrm{K}_{4}$ 系とするとき，粒子は $r_{4}$ の位置で速度 $v_{4}$, 回転角速度 $\omega_{4}$ で運動している. ここで，次章の流体運動につなげるため， $\boldsymbol{r}_{4}$ を基準 動座標原点の位置 $\boldsymbol{r}_{\mathrm{w}}$ と粒子の相対位置 $\boldsymbol{r}_{\mathrm{r}}$ との和で表 し，また，絶対速度 $\dot{\boldsymbol{r}}_{4}$ を基準動座標原点の速度 $\boldsymbol{w}$ と, 粒子の相詨速度 $v_{\mathrm{r}}$ との和で表し，

$$
\boldsymbol{r}_{4}=\underbrace{\boldsymbol{r}_{n}+\sum_{i=0}^{2} \boldsymbol{l}_{i}}_{\boldsymbol{r}_{\mathrm{w}}}+\left\{\left(\begin{array}{c}
(b+r \sin \phi) \cos \theta \\
(b+r \sin \phi) \sin \theta \\
r \cos \phi
\end{array}\right)-\boldsymbol{l}_{2}\right\}
$$

$$
\boldsymbol{v} \triangleq \dot{\boldsymbol{r}}_{4}=\underbrace{\dot{\boldsymbol{r}}_{n}+\boldsymbol{\omega}_{n} \times \boldsymbol{l}_{0}+\sum_{i=1}^{2} \boldsymbol{\omega}_{i} \times \boldsymbol{l}_{i}}_{\boldsymbol{w}}+\underbrace{\left(\dot{\boldsymbol{l}}_{3}\right)}_{\boldsymbol{v}_{\mathrm{r}}}
$$

$\omega_{4}=\omega_{n}+\omega_{\psi}$

$$
\begin{aligned}
\dot{\boldsymbol{w}}= & \ddot{\boldsymbol{r}}_{n}+\dot{\boldsymbol{\omega}}_{n} \times \boldsymbol{l}_{0}+\sum_{i=1}^{2} \dot{\boldsymbol{\omega}}_{i} \times \boldsymbol{l}_{i}+\boldsymbol{\omega}_{n} \times\left(\boldsymbol{\omega}_{n} \times \boldsymbol{l}_{0}\right) \\
& +\sum_{i=1}^{2} \boldsymbol{\omega}_{i} \times\left(\boldsymbol{\omega}_{i} \times \boldsymbol{l}_{i}\right)
\end{aligned}
$$

となる.ここに，スカラ $r, \theta, \phi, b$ は表 1 のもの， $\omega_{\psi}$ は $\mathrm{K}_{n}$ 系以降の相対角速度である. また，( ‘) は相対

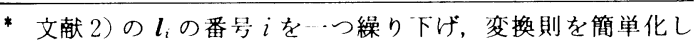
た。
量を微分した後, $\mathrm{K}_{m}$ 系から見た量に変換するオぺ レータである. $\mathrm{K}_{3}$ 系の単位べクトルをそれぞれ $\boldsymbol{e}_{\varphi}$, $\boldsymbol{e}_{\theta}, \boldsymbol{e}_{r}$ とする.

\section{3. 流体運動方程式}

動座標系で流体運動を取り扱う。相対系の連続方程 式は積分形式で5)

$$
\frac{\mathrm{d}}{\mathrm{d} t} \int_{V_{a}} \rho \mathrm{d} V+\int_{S_{a}} \rho \boldsymbol{v}_{r} \cdot \boldsymbol{n} \mathrm{d} S=0
$$

また, 運動量方程式は付録の 1. から,

$$
\begin{aligned}
& \frac{\mathrm{d}}{\mathrm{d} t} \int_{V_{a}} \rho \boldsymbol{v}_{r} \mathrm{~d} V+\int_{V_{a}} \frac{\partial}{\partial t}(\rho \boldsymbol{w}) \mathrm{d} V \\
& \quad+\int_{S_{a}} \rho\left\{\boldsymbol{v}_{r}\left(\boldsymbol{v}_{r} \cdot \boldsymbol{n}\right)+\boldsymbol{w}\left(\boldsymbol{v}_{r} \cdot \boldsymbol{n}\right)+\boldsymbol{w}(\boldsymbol{w} \cdot \boldsymbol{n})\right\} \mathrm{d} S \\
& =\boldsymbol{F}_{n}+\boldsymbol{F}_{t}+\boldsymbol{F}_{f}+\int_{V_{a}} \rho \boldsymbol{B} \mathrm{d} V
\end{aligned}
$$

である.ここに， $\boldsymbol{B}$ は体積力， $S_{a}$ は任意に動く閉じ た検査面， $V_{a}$ はそれに井まれた体積であり， $S_{a}$ は動 かない固定壁 $S_{0}$, 検査面内への流体の出入口 $S_{2}$ など から成っている， $\boldsymbol{F}_{n}$ は検査面の出入り口の王力差に よる力, $\boldsymbol{F}_{t}$ は検査面に沿って働く力であり,それら の $y_{3}$ 方向成分は

$$
\begin{aligned}
& \boldsymbol{F}_{n} \cdot \boldsymbol{e}_{\theta}=\int_{s_{a}}(-p n) \mathrm{d} S=-\Delta p S_{2} \\
& \boldsymbol{F}_{t} \cdot \boldsymbol{e}_{\theta}=\int_{s_{a}} \tau_{\theta} \mathrm{d} S
\end{aligned}
$$

ここに，pは王力， $\tau_{\theta}$ は壁面せん断応力である， $\boldsymbol{F}_{\mathrm{f}}$ はその他の外力, 例えば膜変位をとらえる電極用リ一 ド線のばね力などである， $\rho$ を流体の密度， $\mu$ を流体 の粘性係数, $\nu$ を動粘性係数 $(\mu / \rho)$ とする.

流体運動に関し以下の仮定を設ける.

1）流体は非王縮性，すべりなし，粘性層流とす る.

2）速度の二乗オーダが省略できる程度の遅い流れ とする。

3）表面力，体積力 $\boldsymbol{B}$ は考えない.

4）弁近傍を除き $y_{3}$ 方向の王力勾配 $\partial p / \partial \theta$ は一 定, 速度勾配は $\partial v_{\theta} / \partial \theta=0$.

5）管断面内の径方向流動, 回転流動は考えない, $v_{r}=0, \quad v_{\varphi}=0$

6） $b \gg a, \partial v_{\theta} / \partial \phi \fallingdotseq 0$, および $v_{\theta}$ は小さく，直管 近似が成り立つ.

本報の主題は回転運動であるから，付録式 (A 3) の角運動量方程式を用いるべきであるが, 円環系流れ のマクロなメカニズムを把握するため煩雑さを避け, 仮定 6)により管曲がりの影響が無視でさるものとし 


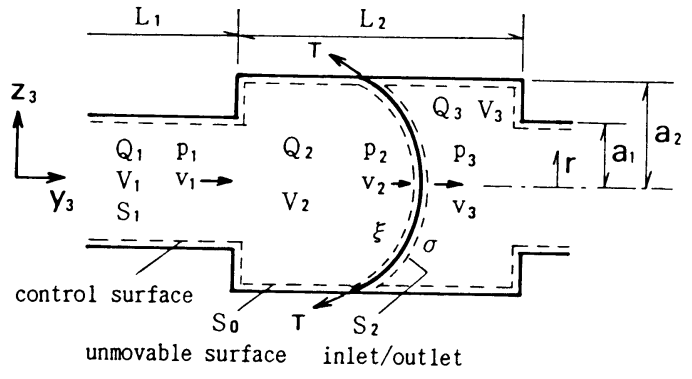

Fig. 2 Membrane value in a torus tube. Control surface $S_{a}(t)=S_{0}+S_{1}+S_{2}$. $\boldsymbol{w}=0$ at $S_{0}$, membrane deflection velocity $\boldsymbol{v}_{r}$ at $S_{2}$

て，式（8）を用いる.

連続の式 (7) は具体的に付録式 (A 4) で与えられ, $v_{\varphi}=0$ の場合が存在するので，簡単のためこのよらな 管断面に関する一様な流れを扱う。 $y_{3}$ 方向に関する Navier-Stokes の式は付録式（A 5) で与えられるが, 上記の仮定に基づく定常流れの流速と平均流速（以 降, 平均值には一を付ける）は

$$
v_{\theta}=\frac{a^{2}-r^{2}}{4 \mu b} \frac{\partial p}{\partial \theta}, \quad \hat{v}_{\theta}=\frac{a^{2}}{8 \mu b} \frac{\partial p}{\partial \theta}
$$

で表される，管内の動的流れに対する管摩擦は，等価 粘性抵抗表示式6)などで表されるが，ここでは擬定常 表示式が適用できる範冊の変動 (角振動数), すなわ ち, $v_{\theta}$ と $\Delta p$ の関係が式 (10) で近似できるものとす る.

\section{4. 角運動センサの構成}

\section{1 流れの中の弾性膜}

環状容器内に置かれた弁にもれがない場合として, 図 2 のような円環状容器と閉じた円形膜弁を考える. 原点 $\mathrm{O}_{1}$ から見て管中心線の管長がそれぞれ $L_{1}, L_{2}$, 管断面半径がそれぞれ $a_{1}, a_{2}$ であり，また断面積，体 積, 流量, 圧力, 流速はそれぞれ $S_{i}, V_{i}, Q_{i}, p_{i}, v_{i}(i$ $=1,2, \cdots)$ である. 弁膜には一様に差压 $\Delta p$ がかかる ものとする. 膜の面密度を $\sigma$, 単位長さ当たりの張力 を $T$, 変位を $\xi$ とて, 膜の変形方程式

$$
T \nabla^{2} \xi-\sigma \xi=-\Delta p
$$

に颃いて， $\dot{\xi}=0$ なるゆっくりした滑らかな変形，又 は $\sigma=0$ なる質量のない膜を考える. この解から平均 変位 $\widehat{\xi}$ を算出し，それを用い

$$
\Delta p=8 T \widehat{\xi} / a_{2}{ }^{2}
$$

を得る. 膜の変形による平均流量 $Q_{2}$ と連続の式から $\widehat{v}_{2}=\dot{\vec{\xi}}$ となる. な捛, 弁膜に作用する $y_{3}$ 方向の外力 は $\Delta p$ 以外に考えないものとする.

図 2 の点線で囲った検査面に対し, 環状方向に運動 量の定理を適用する7). 式 (8) の左辺から順に, 第 1

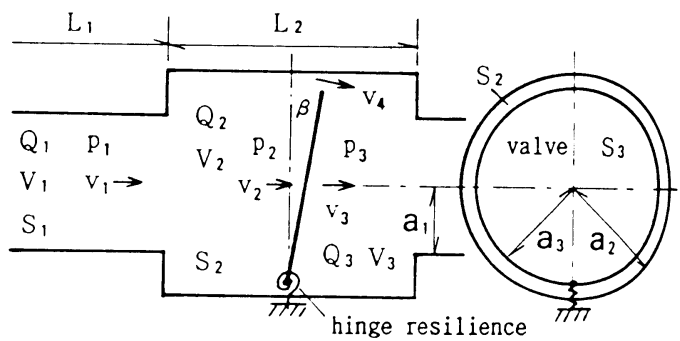

Fig. 3 Hinge valve with leakage flow. l's is leakage velocity

項は $\rho \ddot{\bar{\xi}} S_{2} \cdot 2 \pi h$, 第 2 項 は $\rho \dot{\boldsymbol{w}} \bullet \boldsymbol{e}_{\theta}\left(S_{1} L_{1}+S_{2} L_{2}\right)$, 第 3 項は 0 , 第 4 項は $-\Delta p S_{2}$, 第 5 項は $\left(-8 \mu \dot{\xi} / a_{1}^{2}\right)$. $S_{2} L_{1}, \boldsymbol{F}_{f}$ と $\boldsymbol{B}$ は0であるから, 次の近似方程式を得 る.

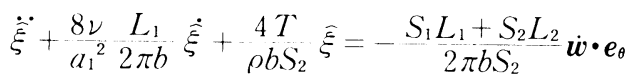

・様な管径をもつ归環容器は一つの構成形態であ る.そのとき, 式 (13) は

$$
\ddot{\vec{\xi}}+2 \zeta \omega_{0} \dot{\xi}+\omega_{0}^{2} \bar{\xi}=-u_{0} \dot{\boldsymbol{w}} \cdot \boldsymbol{e}_{\theta}
$$

の拢動方程式となる。ただし，

$$
\omega_{0}=\sqrt{\frac{4 T}{\rho b S_{2}}}, \quad \zeta=\frac{2 \mu}{a_{2}} \sqrt{\frac{\pi b}{\rho T}}, \quad \mathcal{u}_{0}=1
$$

よって, もれのない膜の我では， 張力 $T$ が大 $(\zeta<1)$ なるとき角加速度を, 逆に $a_{2}$,

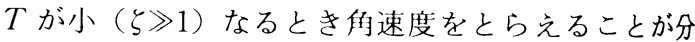
かる.

\section{2 漏れのあるヒンジ弁}

管内の流れは同打と粘性才が支配的な低レイノルズ 数流れとし，弁问りでストークス近似が成り立つもの とする ${ }^{8)}$. 図 3 に拈いて, 容器内壁・弁間のすきま面 積は一般に $S_{4}=\left(S_{2}-S_{3}\right) \ll S_{3}$ であるから, 弁前後で 流れはよどんでおり，それらのよどみ点の压力を加， p 3 とする。な拝，低レイノルズ数，ストークス流れ からそれぞれ $p_{3}$ と $p_{4}$ は等しく，曆流で流線模様は前 後対称と仮定できる. 弁近傍の起常流れの方程式

$$
\frac{\partial p}{b \partial \theta}=\mu \nabla^{2} v_{4}
$$

に颃いて，前節と同様に直恦管近似とすれば，もれの 平均流速は

$$
\begin{aligned}
\widehat{v}_{4} & =\int_{a_{3}}^{a_{2}} \frac{2 \pi r{ }_{4} \mathrm{~d} r}{\left(a_{2}^{2}-a_{3}{ }^{2}\right)} \\
& =-\frac{1}{8 \mu b} \frac{\partial p}{\partial \theta}\left(a_{2}-a_{3}\right)^{2}
\end{aligned}
$$

のオーダとなる.ここで，成力変化が $b \partial \theta$ に関し $\mathrm{O}\left(a_{2}-a_{3}\right)$ の範明にあると敒起 ${ }^{8)}$ ，弁に及洼す抗力 


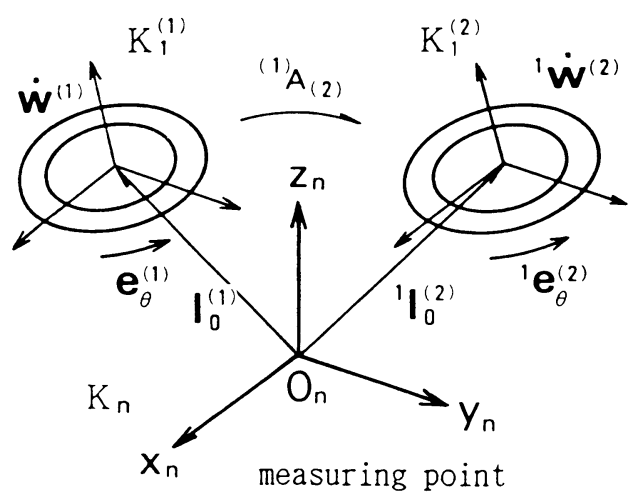

Fig. 4 Angular motion sensor system

を線形化すると，

$$
\Delta p=-8 \mu K \frac{\hat{v}_{4}}{a_{2}-a_{3}}
$$

となる。よって，式（16）のもれ平均流速は次のよう に書き換光られる。

$$
\bar{v}_{4}=\frac{1}{D}(k \bar{\xi}+c \dot{\bar{\xi}})
$$

ただし， $\bar{\xi}=a_{3} \beta ， \beta$ は升のた扮れ角，KはO(1)の 定数, $1 / D$ は定数 $\left(a_{2}-a_{3}\right) / 8 \mu K S_{3}, k, c$ はそれぞれ 井ヒンジ部の[回転ば权定数，叮転減寒係数に刘志した 壮ね定数, 減衰係数である。更に弁ヒンジ部の減衰力 生，流体摩擦に比べ無視できるとして省略し，連続の 方程式 (7), 運動量方程式 (8) から式 (14) 型の方程 式

$$
\begin{aligned}
\ddot{\tilde{\xi}}+ & \left(\frac{8 \nu}{a_{1}{ }^{2}} \cdot \frac{L_{1}}{2 \pi b}+\frac{S_{4}}{S_{3} D} k\right) \dot{\xi} \\
& +k\left(\frac{1}{2 \pi \rho b S_{3}}+\frac{8 \nu}{a_{1}{ }^{2}} \cdot \frac{L_{1}}{2 \pi b} \cdot S_{4} S_{3} D\right) \xi \\
= & -\frac{S_{1} L_{1}+S_{2} L_{2}}{2 \pi b S_{3}} \cdot \dot{\boldsymbol{w}} \cdot \boldsymbol{e}_{\theta}
\end{aligned}
$$

を得る。もれ流動は見かけ、はばね力と粘性力を増加さ せている，もれを考觉なければト:式は式（13）に一致 する.

\section{3 空間 構 成}

相等しい:つつの归環系を同一方向に配置することに より, 式 (6)の $\dot{\boldsymbol{w}}$ 中の成分 $\ddot{\boldsymbol{r}}_{n}$ を除去することがで

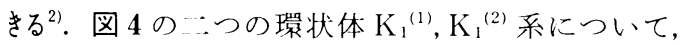
計測点 $\mathrm{O}_{n}$ からセンサ原点 $\mathrm{O}_{1}$ までの践離をそれぞれ $\boldsymbol{h}^{(1)},{ }^{1} \boldsymbol{l}_{0}^{(2)}$ ，弁の变位をそれぞれ $\xi^{(1)}, \xi^{(2)}$ とする。環状 体の周方向の単位べクトルを双方とも $\boldsymbol{e}_{\theta}$ とする。 $\mathrm{K}_{1}^{(2)}$ から $\mathrm{K}_{1}{ }^{(1)} へ$ 変換は, 式 (2)を使用する。な お，図中のベクトル方:有の添字は分かりやすくする ため付けてある，角速度の：乗項が省略できるとき，
この二つの系で式 (14) の差を取ることにより, 右辺 の励振角加速度 $\dot{Q}(t)$ は

$$
\dot{\Omega}(t) \triangleq u_{0}\left\{\dot{\boldsymbol{\omega}}_{n} \times\left(\boldsymbol{l}_{0}^{(2)}-\boldsymbol{l}_{0}^{(1)}\right)+\sum_{i=1}^{2} \dot{\boldsymbol{\omega}}_{i} \times\left(\boldsymbol{l}_{i}^{(2)}-\boldsymbol{l}_{i}^{(1)}\right)\right\} \cdot \boldsymbol{e}_{\theta}
$$

となる、したがって, 計測値 $\left(\xi^{(1)}-\xi^{(2)}\right)$ から， $\mathrm{K}_{n}$ 系 の鿇加速度あるいは角速度が容易に計算される。

\section{4 設 計 例}

角速度がゆっくりと正弦的に変動する回転台の角速 度を計測するものとする，回転軸に円環・液体系セン サの座標 $\mathrm{K}_{1}$ 系を合わせるとき，式(6)に扔いて， $\ddot{\boldsymbol{r}}_{n}=0, \quad \boldsymbol{l}_{0}=\boldsymbol{l}_{1}=0, \quad \boldsymbol{l}_{2}=\left(\begin{array}{lll}b & 0 & 0\end{array}\right)^{\mathrm{T}}, \quad \boldsymbol{\omega}_{n}=\left(\begin{array}{lll}0 & 0 & \omega_{n}\end{array}\right)^{\mathrm{T}}$, $\omega_{1}=\omega_{2}=\omega_{n}$ である. 添字 T は転置行列を示す．角 振動数 $\lambda$ を用い, $\omega_{n}=u_{1} \lambda \sin \lambda t$ なる角速度入力を 考光る. $t$ が $0 \sim \pi / \lambda \mathrm{s}$ 間に台が 1 回転するものとす ると $u_{1}=\pi, \quad \dot{\boldsymbol{w}} \cdot \boldsymbol{e}_{\theta}=b u_{1} \lambda^{2} \cos \lambda t$ である.

式 (19)，(14）を基に極めて柔らかい弁を作成するこ ととする. 円環部のサイズは $b=1, a_{1}=0.06, a_{2}=$ $0.3, a_{3}=0.28, L_{1}=4.71, L_{2}=1.57$, 単位は $\times 10^{-2}$ $\mathrm{m}$ である. $\rho, \mu, \nu$ は $20^{\circ} \mathrm{C}$ の水のものとする. $\omega_{0}=1$ とするとき， $k=0.312 \times 10^{-3} \mathrm{~kg} \cdot \mathrm{s}^{-2}, \quad \zeta=8.35$ とな る.

式 (14)の解及び式 (18), (7) から

$$
\begin{array}{r}
\hat{v}_{2}=\frac{1}{S_{2}}\left(S_{3} \dot{\xi}+\frac{S_{4}}{D} k \hat{\xi}\right) \leqq \frac{S_{3}}{S_{2}} \frac{u_{0} u_{1} b p^{2} \lambda}{\sqrt{\left(1-p^{2}\right)^{2}+(2 \zeta p)^{2}}} \\
\left(p=\lambda / \omega_{0}\right) \quad(21)
\end{array}
$$

が求まり, $p=0.8$ のとき, $\hat{v}_{2}=0.335 \times 10^{-3} \mathrm{~ms}^{-1}$ と なる，ただし，弁の減衰係数 $c$ を省略した。これら から，レイノルズ数 $\operatorname{Re}=2 a_{2} \hat{v}_{2} / \nu=2$ となり，十分遅 い流れとなっている.

\section{5. 考察}

ここで取り扱った理論は，直円管内流動を基にして 円環管内流動を近似した。これは，式（A 3)におい て $\boldsymbol{v}_{r}$ を平均流速， $\boldsymbol{r}_{r}$ を平均距離と解釈したことによ る. 円環体の半径がその管半径に比べ十分大きいとき には，曲がり流れの影響が小さく，この近似が成立す ると思われる．また，管摩摖をいかに見積るかは難し いところであるが，静止状態から急に流れ出すトラン ジェント流泉に怙いて，始めの 1 サイクルは非定常管 摩擦が定常管摩擦と注注等しいことから, 擬定常表示 式古をを採用した。したがって，断続的な生体運動の計 測などに対する計測センサの設計に当たっては，注ぼ 妥当な見積りであると考兄られる.

右:有一つの三半規管が 3 軸とも 4.3 節のように $\boldsymbol{e}_{\boldsymbol{\theta}}$ がそろっているとは言い難い，しかし，工学的には式 


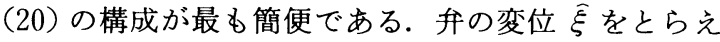
る一つの方法は，流体を電解質溶液とし ${ }^{10)}$ ，弁を㣣む 一対の固定電極と弁に付加した可動電極によりブリッ ジを構成して測定する. 設計例の場合は, $\bar{\xi} \leqq 0.48 \times$ $10^{-3} \mathrm{~m}$ と小さいが測定可能である ${ }^{11)}$.

遅い粘性流体中で球が受ける抗力は, 流れの慣性項 を無視したストークスの近似式で表されるが， Re ０.7で実験と合わなくなり，一般に Re $\leqq 1$ の範用で 利用されている，流れに直交する円板，円柱も同様で ある.それらに比べ，設計例では $\operatorname{Re} \sim 2$ と大きい． しかし，本報の理論自体が粗い近似から成っているた め, 弁回りの遅い流れに適用したストークス近似は, 全体の誤差範囲にあると思われる.

\section{6. ま と め}

半規管に類似した円環・液体系の空間運動について, 2 種類の弁構造に対する振動型の近似方程式を導き, 弁の変位を計測することにより, 角運動の検出が可能 であることを記述し，以下のことが分かった。

（1）もれのない膜型の弁では, 膜変位は管径が大, 膜張力が大なるとさ角加速度を, 逆に管径が小, 膜張力が小なるとき減衰係数が大となり角速度 成分をとらえる構成となる。

（2）もれのあるヒンジ弁では，弁が直管内で抗力 を受け傾くが，弁回りのもれ流れを面積流量計 のテーパ管内フロートの移動に近似させてその 抗力を線形化することができる、その結果，も れ流動は見かけ上弁のばね力と粘性抵抗力に影 響を与える。

（3）相等しい二つの円環系を同一方向に配置する ことにより，計測部位に至るまでの中間リンク 系の加速度成分を除去することができる．角速 度の二乗項が省略できる場合には, この 2 系の 弁変位の計測值の差から, 計測点の角加速度あ るいは角速度を容易に算出することができる.

\section{[付 録]}

\section{1. 動座標系から見た流体の相対運動量方程式}

速度 $\boldsymbol{w} て ゙$ 動く座標系 $\mathrm{K}_{m}$ 系から見て（ベクトルの 左肩添字の $\mathrm{m}$ を省略する), 静止系に対する速度 $\boldsymbol{v}$ による運動量方程式, 例えば文献 5) p.212 に, $\boldsymbol{v}=\boldsymbol{w}$ $+\boldsymbol{v}_{r}$ を代入し, 一般化 Reynolds の輸送定理

$$
\frac{\mathrm{d}}{\mathrm{d} t} \int_{V_{a}} \psi \mathrm{d} V=\int_{v_{a}} \frac{\partial \psi}{\partial t} \mathrm{~d} V+\int_{s_{a}} \psi(\boldsymbol{w} \cdot \boldsymbol{n}) \mathrm{d} S
$$

を用いて導く。をた，それはCauchy の運動方程式か らも導くことができる。

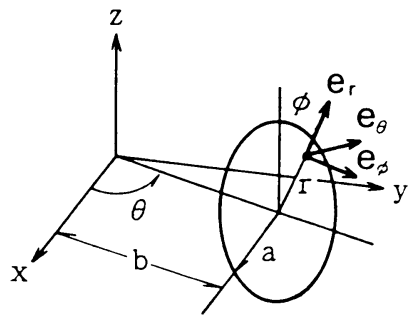

Fig. A1

\section{2. 動座標系から見た流体の相対角運動量方程式}

一般に見当たらないので，ここに導出しておく． Cauchy の運動方程式を変形した積分表示式

$$
\begin{gathered}
\int_{V_{a}} \frac{\partial}{\partial t}(\boldsymbol{r} \times \rho \boldsymbol{v}) \mathrm{d} V+\int_{S_{a}}(\boldsymbol{r} \times \rho \boldsymbol{v} \boldsymbol{v} \cdot \boldsymbol{n}) \mathrm{d} S \\
=\int_{S_{a}}\left(\boldsymbol{r} \times \boldsymbol{t}^{(n)}\right) \mathrm{d} S+\int_{V_{a}}(\boldsymbol{r} \times \rho \boldsymbol{B}) \mathrm{d} V
\end{gathered}
$$

ただし， $\boldsymbol{t}^{(n)}$ は面に㗢く力, $\boldsymbol{B}$ は外力, $\boldsymbol{r}$ は本文式

（3）の $\boldsymbol{r}_{\mathbf{4}}$ に当たる. これに式 (A 1) を代入し

$$
\begin{aligned}
& \frac{\mathrm{d}}{\mathrm{d} t} \int_{v_{a}}(\boldsymbol{r} \times \rho \boldsymbol{v}) \mathrm{d} V+\int_{S_{a}}\left(\boldsymbol{r} \times \rho \boldsymbol{v} \boldsymbol{v}_{r} \cdot \boldsymbol{n}\right) \mathrm{d} S \\
& \quad=(\mathrm{A} 2) \text { の右辺 }
\end{aligned}
$$

この左辺第 1 項を式 (4) と（A 1) を用いて変形し, 更に式（3）を代入し，運動量方程式に相当する部分を 差し引くと次のように得られる.

$$
\begin{aligned}
& \frac{\mathrm{d}}{\mathrm{d} t} \int_{V_{a}}\left(\boldsymbol{r}_{r} \times \rho \boldsymbol{v}_{r}\right) \mathrm{d} V+\int_{V_{a}}\left\{\boldsymbol{r}_{r} \times \frac{\partial}{\partial t}(\rho \boldsymbol{w})\right\} \mathrm{d} V \\
& \quad+\int_{S_{a}}\left\{\boldsymbol{r}_{r} \times \rho\left(\boldsymbol{v}_{r} \boldsymbol{v}_{r} \cdot \boldsymbol{n}+\boldsymbol{w} \boldsymbol{v}_{r} \cdot \boldsymbol{n}+\boldsymbol{w} \boldsymbol{w} \cdot \boldsymbol{n}\right) \mathrm{d} S\right. \\
& \left.=\int_{S_{a}}\left(\boldsymbol{r}_{r} \times \boldsymbol{t}^{(n)}\right) \mathrm{d} S+\int_{V_{a}}\left(\boldsymbol{r}_{r} \times \rho \boldsymbol{B}\right) \mathrm{d} V \quad \text { (A } 3\right)
\end{aligned}
$$

さらに, $\boldsymbol{t}^{(n)}$ は $\boldsymbol{F}_{n}, \boldsymbol{F}_{t}$ に分解できる.

3. 円環管内流動方程式

目 $\mathbf{A} 1$ に括いて, $h_{1}=r, h_{2}=b+r \sin \phi, h_{3}=1$, 及び流速 $\boldsymbol{v}=\left(\begin{array}{lll}v_{\varphi} & v_{\theta} & v_{r}\end{array}\right)^{\mathrm{T}}$ を定義する.

連続の式は

$$
\begin{aligned}
& \frac{\partial \rho}{\partial t}+\rho\left\{\frac{1}{r} \frac{\partial v_{\varphi}}{\partial \varphi}+\frac{1}{h_{2}} \frac{\partial v_{\theta}}{\partial \theta}+\frac{\partial v_{r}}{\partial r} \frac{\cos \varphi}{h_{2}} v_{\varphi}\right. \\
& \left.+\left(\frac{1}{r}+\frac{\sin \varphi}{h_{2}}\right) v_{r}\right\}=0
\end{aligned}
$$

非王縮性流体に対する Navier-Stokes の方程式の分 解表示 $\left(\boldsymbol{e}_{\theta}\right.$ 方向成分) は

$$
\begin{aligned}
& \left(\frac{\partial \boldsymbol{v}}{\partial t}+\boldsymbol{v} \cdot \operatorname{grad} \boldsymbol{v}\right) \cdot \boldsymbol{e}_{\theta}=\frac{\partial v_{\theta}}{\partial t}+\frac{v_{\varphi}}{r} \frac{\partial v_{\theta}}{\partial \varphi}+\frac{v_{\theta}}{h_{2}} \frac{\partial v_{\theta}}{\partial \theta} \\
& \quad+v_{r} \frac{\partial v_{\theta}}{\partial r}+\frac{\cos \varphi}{h_{2}} v_{\varphi} v_{\theta}+\frac{\sin \varphi}{h_{2}} v_{\theta} v_{r} \\
& \left(-\frac{1}{\rho} \operatorname{grad} \phi\right) \cdot \boldsymbol{e}_{\theta}=-\frac{1}{\rho h_{2}} \frac{\partial p}{\partial \theta} \\
& \left(\nabla^{2} \boldsymbol{v}\right) \cdot \boldsymbol{e}_{\theta}=\nabla^{2} v_{\theta}+\frac{2 \cos \varphi}{h_{2}{ }^{2}} \frac{\partial v_{\varphi}}{\partial \theta}+\frac{2 \sin \varphi}{h_{2}{ }^{2}} \frac{\partial v_{r}}{\partial \theta}-\frac{v_{\theta}}{h_{2}{ }^{2}}
\end{aligned}
$$

ただし， $\nabla^{2} \boldsymbol{v}$ は $\nabla(\nabla \cdot \boldsymbol{v})-\nabla \times(\nabla \times \boldsymbol{v})$ から計算する. ここに,

$$
\nabla^{2}=\frac{1}{r^{2}} \frac{\partial^{2}}{\partial \varphi^{2}}+\frac{1}{h_{2}^{2}}-\frac{\partial^{2}}{\partial \theta^{2}}+\frac{\partial^{2}}{\partial r^{2}}
$$




$$
+\frac{\cos \varphi}{r h_{2}} \frac{\partial}{\partial \varphi}+\left(\frac{1}{r}+\frac{\sin \varphi}{h_{2}}\right) \frac{\partial}{\partial r}
$$

である.

\section{参考 文 献}

1）西原主計，和田充雄，橋本亮一：動物重心維持機能に関 する調査研究，製品科学研究所報告，109（1987） 45 .

2）西原主計, 久場康良：加速度計を用いた角運動センサ, 精密工学会誌, 55，（1989） 139.

3) A. A. J. Van Egmond, J. J. Groen and L. B. W. Jong. kees: The Mechanics of the Semicircular Canal, J. Physiol., 110, (1949) 1.

4) J. Y. S. Luh, M. W. Walker and R. P. C. Paul : On-Line Computational Scheme for Mechanical Manipulators, Trans. ASME, DSMC 102, (1980) 69.
5）棚橋隆彦：基礎流体工学入門，コロナ社，(1976).

6) 近江宗一, 井口 学, 碓井建夫：円管内脈動流れの流動 形態と摩擦損失, 日本機械学会論文集, B 編, 46, 405 （1980） 846.

7）笠井浩爾：弾性支持を有するポペット弁の安定性につい $\tau$ ， 日本機械学会論文集（第 2 部)，34，260（1968）655.

8）金住順二：フロート形面積流量計の流量係数に関する考 察, 計測自動制御学会論文集, 18, 4 (1982) 390 .

9) W. Zielke : Frequency-Dependent Friction in Transient Pipe Flow, Trans. ASME, J. Basic Eng., 110, (1968) 109.

10）西原主計, 橋本亮一, 松本墇一：姿勢センサの開発, 製 品科学研究所報告, 113 (1988) 29.

11）西原主計, 橋本亮一, 松本璋一: 電解質溶液を用いた傾 き角センサ，精密工学会誌，53，5（1987） 767.

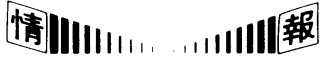

\section{総合的切削状態認識方法に関する研究}

(財)工作機械技術振興財団では, 標記の件について昭 和 63 年 7 月より東京工業大学伊東誼教授, 新野秀憲助 教授にその研究を依嘱していたが，このほどその研究成 果がまとめられた。

ところで, 近年, FMS（フレキシブル生産システム） に代表される生産の自動化，無人化が著しく進展してい く中で，切削加工の状態をインプロセスで認識可能なセ ンシング技術を開発することが，より以上の生産システ 厶の高度化, 知能化を図る上で極めて重要な課題となっ ている.すなわち，無人運転下で生産システムを効率 的, かつ安全に稼働させるためには, 生産システムを構 成する工作機械及び加工システム全体のインプロセス状 態認識, 特に加工状態の自動認識をいかに行らかといら ことが重要な問題となってくる.

ところで，工具，工作機械，亡作物などから構成され る一連のシステムに括いて，工作物と亡具のインタ フェースは, 加工空間に扣いて形状創成運動を行 5上で の重要な接点であり，その部分の状態を表す情報を効率 的に獲得し, 正確に状態を認識することが必要不可久で ある.

具体的なセンシングの対象としては例えば, 以下のよ らな情報が挙げられる.

（1）切削動力, 及びその変動

(2) 工具材種及び亡作物材質

（3）切りくず形状
（4）切りくず排出状態

(5) 工具の摩耗

(6) 工具の損傷

（7）びびり振動

（8）工作物の表面性状

(9) 工具の熱変形

(10) 工作物の熱変形

（11）工具・工作物・工作機械系の異常，故障

(12) 切削条件

上述のような加工環境に打ける状態に関係する数多く の情報をリアルタイムに，かつ効率的に得ることができ れば，生産システムの無人化を実現する上で重要な技術 が確立できることになる。

このような切削状態の認識, センシングといった問題 に対しては, 従来から切削抵抗や工具摩耗に測定を主な 目的とした切削動力計や $\mathrm{AE}$ センなどが開発されてき た。しかし，それらの大部分はセンサからの出力信号を もとに単一の現象を把握しょうとしたものであり，ひと つのセンサからの出力信号を最大限に活用して生産シス テムに打ける総合的な切削状態の認識を行扣うとする方 法についてはほとんど検討されていない，すなわちひと つのセンサから可能な限りの数多くの情報を得ようとす る観点からの研究はほとんど検討されていない. 